\title{
CLUTCH SIZE \\ OF THE AMERICAN AVOCET \\ IN THE PRAIRIE PROVINCES
}

NORBERT G. KONDLA, Parks Division, Alberta Recreation, Parks \& Wildlife, 9912 - 106 Street, Edmonton, and HAROLD W. PINEL, 1017 - 19 Avenue, N.W., Calgary, Alberta

The American Avocet is a large, showy bird that is fairly common in suitable habitat across the prairie region of Canada. Considering the ease with which this species can be observed, surprisingly little information is available in the literature on the breeding biology of this species in Canada.

Nesting data was accumulated for the American Avocet from: Prairie Nest Record Scheme; Calgary Field Naturalists' Society observation files; United States Fish and Wildlife Service, Migratory Bird and Habitat Research Laboratory; Royal Ontario Museum; Field Museum of Natural History; Santa Barbara Museum of Natural History; University of Massachusetts; National Museum of Natural Sciences; Western Foundation of Vertebrate Zoology; and University of Wisconsin. As well, the authors used their own unpublished records (including data subsequently reported by Kondla $\mathrm{a}^{5}$ and the following literature: Bent ${ }^{1}$, Farley ${ }^{2}$, Horsbrugh ${ }^{4}$, Mitchell ${ }^{6}$, Munro $^{7}$, and Vermeer ${ }^{8}$. The data base contains information available up to 1973.

A cursory examination of the data indicated that the information provided by the museums and the literature was not recent, whereas the file cards of the Prairie Nest Record Scheme were. In view of this, the authors initially analyzed the Prairie Nest Record Scheme data separately from the rest. Because the same trends emerged in clutch sizes and clutch size frequency, the data was combined fo the analysis presented here.

A total of 228 avocet nests wer used for clutch-size analysis Relatively few nests were fror Manitoba but good sample sizes ar available from Alberta and Saska chewan (Table 1).

Table 1 shows the overall clutch siz frequency for the sample. Slightl more than one half $(54.8 \%)$ of all nest contained 4 eggs. This was by far th most commonly seen number of egg in an avocet nest. Both 3- and 7-eg nests were second in frequency 0 occurrence. Surprisingly, 8-egg nest ran a close fourth in frequency. Five and 2-egg nests ranked fifth but mos of the 2-egg nests probabl represented incomplete clutches Nine-egg clutches were unknown an one extremely large clutch of $10 \mathrm{egg}$ was reported.

Fifty-six percent of all nests were o islands (Table 2), where 4-egg clutche were again most frequent $(47.6 \%$. followed distantly by 7 -egg clutche $(14.8 \%)$, 3-egg clutches $(10.9 \%)$, and 8 egg clutches $(9.3 \%)$ ). (Table $2 \mathrm{~A}$ ). Othe clutch sizes were relatively infrequent

For nests not on islands, separat percentage figures are not giver because the sample size is 100 and th percentage figure equals the absolut figure. (Table 2B). By far the mos frequent clutch size again was 4 egg $(64 \%)$ but there was a more ever distribution among the other clutcl sizes without a substantial abundance 

Number of Eggs

$\begin{array}{rc} & \text { Alberta } \\ 1 & 4 \\ 2 & 4 \\ 3 & 6 \\ 4 & 44 \\ 5 & 8 \\ 6 & 3 \\ 7 & 19 \\ 8 & 13 \\ 9 & 0 \\ 10 & 0 \\ & 101\end{array}$

101
Number of Nests

Saskatchewan
2
3
10
58
3
3
5
6
0
1
91

Manitoba
2
4
7
23
0
0
0
0
0
0
36

Total

$8(3.5 \%)$

$11(4.8 \%)$

$23(10 \%)$

$125(54.8 \%)$

$11(4.8 \%)$

$6(2.6 \%)$

$24(10.5 \%)$

$19(8.3 \%)$

$0(0 \%)$

$1(0.4 \%)$

228 show that overall, the mean clutch size of Avocets increases as one moves west from Manitoba to Alberta. They also show that mean clutch size for island nests is the same for Alberta and Saskatchewan, indicating that large clutch size is more closely correlated with nesting habitat than other factors.

Derivations of mean clutch size can, of course, vary with the available data and the concept of "clutch" that is used. For example, Vermeer used the

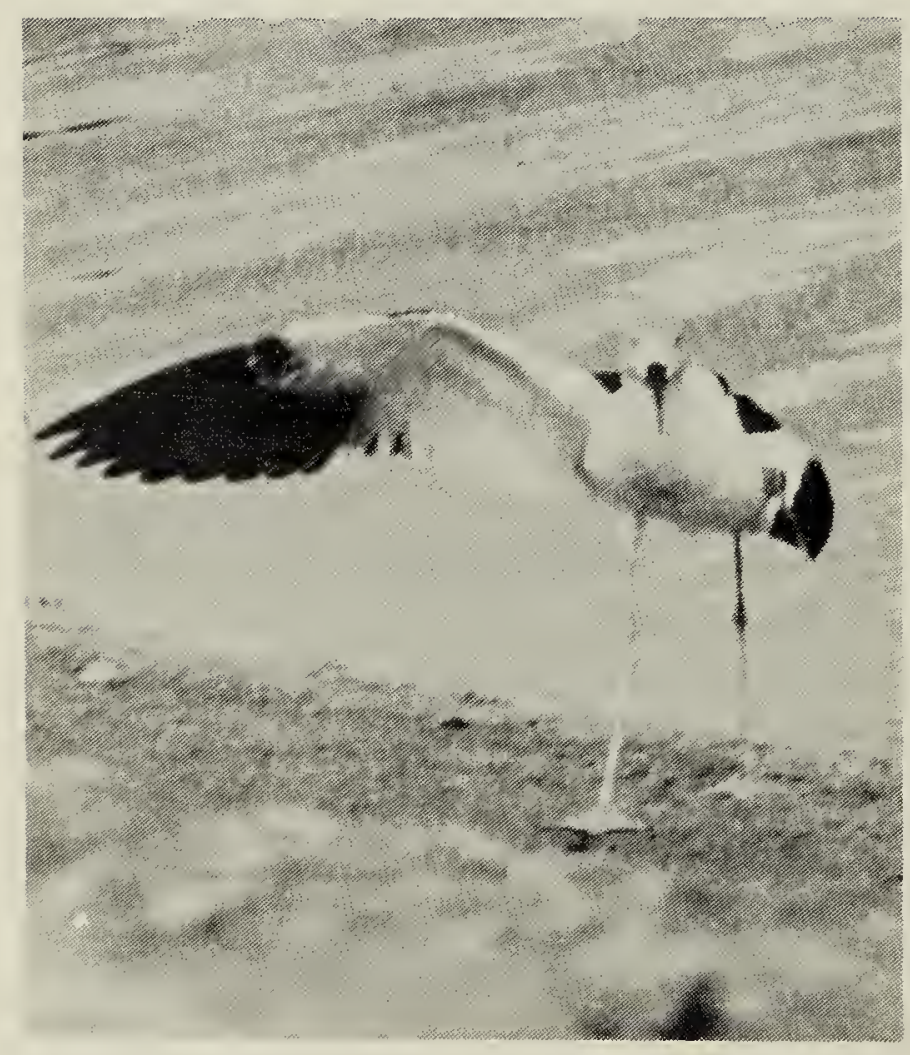

American avocet

Wayne Renaud concept of number of eggs in a nest and thus had a range of 1 to 8 eggs per clutch. $^{8}$ In contrast, Gibson used the concept of total number of eggs laid by one female, thereby excluding nests with 6 or more eggs, although he in cluded 2-egg nests as complete clutches. ${ }^{3}$ Kondla reports that even 4. or 5-egg nests may have composite clutches and hence Gibson's concep is not applied to mean clutch size calculations for this study, since his data does not allow consistent dif ferentiation of eggs from differen birds in one nest. ${ }^{5}$ Vermeer's inclusior of 1 - and 2-egg nests ${ }^{8}$ is questionable since all available information in dicates that such clutches are no complete. For this study we based mean clutch size on nests with more than 3 eggs. Thus, the figures indicate more closely the mean maximum number of eggs that will be incubated.

It was previously pointed out that 7 and 8-egg clutches appear more frequently than 5- or 6-egg clutches This can be explained if one accept that 3-, and more often 4-, egg clutche. are the rule for individual females This assumption is supported b) virtually all available information. I one further assumes that composite nests are most often the result of onl) 
A

No. Island Nest Numbers

$\begin{array}{ccr}\text { Eggs } & \text { Alta } & \text { Sa } \\ 1 & 2 & 1 \\ 2 & 4 & 1 \\ 3 & -4 & 3 \\ 4 & 21 & 23 \\ 5 & 5 & 0 \\ 6 & 3 & 1 \\ 7 & 14 & 5 \\ 8 & 6 & 6 \\ 9 & 0 & 0 \\ 10 & 0 & 1 \\ \text { TOT- } & & \end{array}$

AL $\quad 59$

Sask
1
1
3
23
0
1
5
6
0
1

41

$\begin{array}{cc}\text { Man } & \text { Total } \\ 2 & 5(3.9 \%) \\ 2 & 7(5.4 \%) \\ 7 & 14(10.9 \%) \\ 17 & 61(47.6 \%) \\ 0 & 5(3.9 \%) \\ 0 & 4(3.1 \%) \\ 0 & 19(14.8 \%) \\ 0 & 12(9.3 \%) \\ 0 & 0(0 \%) \\ 0 & 1(0.7 \%)\end{array}$

28

\section{B}

Non-island Nest Numbers

$\begin{array}{rrrr}\text { Total }=\% & \text { Alta } & \text { Sask } & \text { Man } \\ 3 & 2 & 1 & 0 \\ 4 & 0 & 2 & 2 \\ 9 & 2 & 7 & 0 \\ 64 & 23 & 35 & 6 \\ 6 & 3 & 3 & 0 \\ 2 & 0 & 2 & 0 \\ 5 & 5 & 0 & 0 \\ 7 & 7 & 0 & 0 \\ 0 & 0 & 0 & 0 \\ 0 & 0 & 0 & 0 \\ 100 & 42 & 50 & 8\end{array}$

two females, then these composite clutches must be comprised of various combinations of individual 3- and 4egg clutches in proportion to their frequency of occurrence, assuming that a female lays her normal number of eggs in both composite and single clutches. Since 4-egg clutches predominate, most large clutches will have a 4-egg component which, in turn, dictates a 7-or 8-egg composite clutch.

A number of trends and phenomena have been pointed out. These may or may not represent the actual situation since it is not known that the data is representative of the actual situation. For example, large clutches on islands may be reported more often than they actually occur because they are easier to find. More information is needed on the situation in Manitoba to determine if the differences that show up are a reflection of the relatively few nests eported from Manitoba or if they are product of basic environmental and iological differences. Certainly, from an evolutionary perspective, differing environmental conditions in different portions of a species range should be expected to select for differing eproductive strategies.

A thank-you note is warranted for he custodians of the information ources used in this paper. A special note of thanks is extended to many naturalists who have filed observations with nest record schemes and have contributed specimens to museums.

'BENT, A. C. 1927. Life histories of North American shore birds (Part 1). Smithsonian Inst. U. S. Nat. Mus. Bull. 142 (Dover edition, 1962).

${ }^{2}$ FARLEY, F. L. 1932. Birds of the Battle River region, with notes on their present status, migrations, food habits and economic value. Institute of Applied Arts, Edmonton. $85 \mathrm{p}$.

${ }^{3}$ GIBSON, F. 1971. The breeding biology of the American Avocet (Recurvirostra americana) in central Oregon. Condor 73:444-454.

${ }^{4} \mathrm{HORSBRUGH}, \mathrm{C}$. B. 1918. Further notes on birds observed at Alix, Buffalo Lake, and Red Deer in the province of Alberta, Canada, in 1915 and 1916. Ibis 6:477-496.

${ }^{5}$ KONDLA, N. G. 1977. An unusual American Avocet nest. Blue Jay 35:94-95.

${ }^{6}$ MITCHELL, H. H. 1916. Peculiar nesting habits of the Avocet. Condor 19:101.

'MUNRO, J. A. 1936. A study of the Ringbilled Gull in Alberta. Wilson Bulletin 48:169-180.

${ }^{8}$ VERMEER, K. 1971. Large American Avocet clutches at Dowling Lake, Alberta. Blue Jay 29:88. 